\title{
Kajian Tentang Tenun Sesek dari Desa Pringgasela, Lombok Timur, Nusa Tenggara Barat
}

\author{
Ninik Juniati ${ }^{1^{*}}$ \\ 1 Desain Fashion dan Produk Lifestyle, Fakultas Industri Kreatif, Universitas Surabaya, Surabaya- \\ Indonesia \\ * corresponding author: ninik.juniati@staff.ubaya.ac.id
}

\begin{abstract}
Development of fashion world has been following fashion trends including textiles, colors, shapes, fabric textures, and all other details in general fashion terms. One of the exploration and development in textiles is called wastra. Wastra isn't widely known by public. Wastra technique can come in various form, for example Tenun Sesek from Pringgasela Village, East Lombok, West Nusa Tenggara, Indonesia. This research aims to understand Tenun Sesek, from the preparation before weaving process until it serve to customer. This research also consist the explanation to preserve the sustainability process build by weavers in all related matters like designing motifs, dyeing yarn, and the weaving process itself. This research use qualitative descriptive approach with interview and observation as main focused methods. This methods was chosen to explore the subject more briefly. This methods will be supported with documentation photos to capture all the details and validated the data retrieval process. Output from this research is recycling process in every aspect to maintain the product life cycle.
\end{abstract}

Keywords: Tenun Sesek, Weaving, Pringgasela Village

\begin{abstract}
Abstrak-Perkembangan fashion dunia selalu berkembang mengikuti fashion trend yang berlangsung. Fashion trend ini dimulai dengan perkembangan tekstil, warna, bentuk, tekstur kain dan detail busana secara global. Ide-ide untuk eksplorasi kain juga bisa berasal dari wastra yang masih belum begitu dikenal, salah satunya adalah Tenun Sesek dari Desa Pringgasela. Berdasarkan penjelasan tersebut, penelitian ini bertujuan mengkaji tentang wastra yang berasal Desa Pringgasela, Kabupaten Lombok Timur Provinsi Nusa tenggara Barat. Hal-hal yang dikaji terkait tentang proses persiapan sebelum penenunan seperti mendesain motif, pencelupan benang, menenun benang hingga proses keberlanjutan (sustainability) yang dilakukan oleh para penenun di desa Pringgasela tersebut. Metodelogi penelitian ini menggunakan pendekatan kualitatif deskriptif. Metode pengumpulan data penelitian ini menggunakan wawancara, observasi dan dokumentasi. Teknik wawancara dan observasi ini dipilih untuk menggali informasi tentang proses pembuatan Tenun Sesek dan didukung dengan data dokumentasi berupa foto proses pembuatan Tenun Sesek dan proses pengambilan data yang dibutuhkan untuk menunjang penelitian ini. Salah satu hasil penelitian menunjukan bahwa disetiap proses pembuatan Tenun Sesek ini selalu ada proses daur ulang untuk meminimalkan limbah.
\end{abstract}

Kata kunci: Tenun Sesek, penenunan, Desa Pringgasela

\section{PENDAHULUAN \\ Latar Belakang}

Kain Tenun sebagai salah satu wastra Indonesia yang dikenal sebagai kekayaan warisan budaya tidak saja dilihat dari teknik dan aneka ragam corak serta jenis kain yang dibuat, tetapi lebih jauh kita dapat mengenal berbagai fungsi dan arti kain dalam kehidupan masyrakatnya yang mencerminkan adat istiadat, kebudayaan, dan kebiasaan budaya (cultural habit), yang bermuara pada jati dirinya sebagai komponen bangsa Indonesia. Keragaman wastra dihasilkan oleh perbedaan geografis yang memengaruhi corak hidup setiap suku di Indonesia. Perbedaan iklim yang memengaruhi flora dan fauna yang ada di kehidupan masyarakat juga memiliki andil besar terhadap perbedaan gaya hidup dan mata pencaharian sebuah kelompok masyarakat, sehingga yang satu berbeda dengan yang lainnya. Suku-suku yang berada di pegunungan mempunyai corak hidup yang berbeda dengan suku yang berdiam di tepi pantai, mereka yang hidup di pedalaman dan terisolir tentu saja mempunyai kehidupan yang berbeda dengan penduduk yang hidup di wilayah yang sarat dengan lalu lintas perdagangan.

Tenun Ikat di Indonesia umumnya menggunakan kain berserat alam seperti katun dan sutra baik ditenun secara manual oleh masyarakat khususnya ibu-ibu rumah tangga, kegiatan 
menenun dilakukan secara manual dengan menggunakan alat tenun bukan mesin (ATBM) atau dengan alat tenun gedog yang lebih sederhana. Tenun ikat yang ada di Indonesia terdapat 3 jenis, yaitu: 1) Tenun Ikat Lungsi, tenun jenis ini banyak ditemui di wilayah pedalaman yang jauh dari pantai. Suku-suku yang ada di wilayah pedalaman Sumatera, Kalimantan, Sulawesi dan Nusa Tenggara Timur; 2) Tenun Ikat Pakan, daerah yang mengembangkan tradisi Tenun Ikat Pakan karena berada di daerah-daerah pantai seperti Nusa Tenggara Barat, Aceh, Sumatera Selatan, Sulawesi Selatan, Sulawesi Tengah, Jawa dan Bali. Tenun Ikat pakan banyak dipengaruhi oleh budaya India dan Cina karena daerah-daerah yang mengembangkan tenun jenis ini merupakan wilayah perdagangan sehingga sangat memungkinkan para pedagang dari negara lain untuk datang singgah; 3) Tenun Ikat Dobel, hanya ada tiga tempat di dunia yang memiliki Tenun Ikat Dobel, yaitu Jepang yang dikenal dengan Tate-Yoko Gasuri, India yang dikenal dengan Kain Patola, dan Indonesia dengan kain Gringsing yang berasal dari Tenganan, Karangasem, Bali (Kartika, 2007).

Nusa Tenggara Barat merupakan salah satu daerah yang mengembangkan tradisi Tenun Ikat Pakan karena berada di daerah-daerah pantai. Desa Pringgasela merupakan salah satu desa yang ada di Kabupaten Lombok Timur yang memiliki kurang lebih sekitar 420 orang penenun khususnya di Dusun Gubuk Daya. Para penenun ini mengembangkan tradisi tenun yang sering disebut Tenun Sesek secara turun-temurun, nama sesek diambil dari asal suara saat menenun "sek sek". Berdasarkan penelitian tentang wastra khususnya tenun yang sudah pernah dikaji para penulis sebelumnya, masih kurang lengkap kajian tentang Tenun Sesek dari desa Pringgasela. Kajian ini diharapkan dapat memperkenalkan Tenun Sesek dari desa Pringgasela terkait tentang berbagai macam motif dan filosofinya, berbagai proses persiapan, proses penenunan dan penyelesaian (finishing) hingga pemanfaatan limbah dari setiap proses pembuatan kain tenun ini yang dilakukan oleh para penenun di Desa Pringgasela, Kabupaten Lombok Timur Provinsi Nusa Tenggara Barat dan dapat diterima masyarakat, menjadi referensi pengembangan kain tradisional Indonesia lainnya yang tampil menjadi lebih modern sebagai karya seni yang memiliki daya pakai tinggi (wearable art).

\section{Hasil Kajian Sebelumnya} antara lain:

Hasil kajian lain sebelumnya terkait dengan tenun khususnya di daerah Nusa Tenggara,

Tabel 1

Kajian tentang Tenun di wilayah Nusa Tenggara Barat

\begin{tabular}{|c|c|}
\hline Kajian & Hasil Kajian \\
\hline Mardiyanti \& Ismadi (2016) & $\begin{array}{l}\text { Kajian tentang arti simbolik dan fungsi Tenun di masyarakat } \\
\text { Desa Sade, Rembitan, Pujut Lombok Tengah. }\end{array}$ \\
\hline Darma \& Priyadi (2015) & $\begin{array}{l}\text { Kajian tentang keanekaragaman tumbuhan yang digunakan } \\
\text { sebagai pewarna kain tenun suku Sasak Desa Sukarara, } \\
\text { Lombok tengah, Nusa Tenggara Barat. }\end{array}$ \\
\hline Huda, Mi'rajul (2018) & $\begin{array}{l}\text { Kajian tentang perlindungan hukum terhadap kerajinan tenun } \\
\text { songket di desa pringgasela menurut hukum hak kekayaan } \\
\text { intelektual indonesia }\end{array}$ \\
\hline Juniati, Ninik (2019) & $\begin{array}{l}\text { Kajian tentang Tenun Sesek dari Pringgasela sebagai salah satu } \\
\text { bentuk Slow-fashion Product }\end{array}$ \\
\hline
\end{tabular}




\section{METODE}

Metodologi penelitian ini menggunakan pendekatan kualitatif deskriptif. Metode pengumpulan data penelitian ini menggunakan teknik wawancara, observasi dan dokumentasi. Teknik wawancara dan observasi ini dipilih untuk menggali informasi tentang proses pembuatan kain tenun Sesek Pringgasela. Menurut data tahun 2018 di Kantor dusun Gubuk Daya, desa Pringgasela tentang jumlah penenun yang ada di empat RW terdapat kurang lebih sekitar 420 penenun. Narasumber yang dipilih adalah seorang pendamping LPSDM (Lembaga Pengembangan Swadaya Mitra) yang telah menetap di Dusun Gubuk daya selama 5 tahun dan 2 orang penenun senior dengan pertimbangan hanya 2 penenun ini yang masih aktif dan konsisten melakukan pencelupan dan penenunan benang dengan menggunakan pewarna alam hingga saat ini. Teknik dokumentasi dibutuhkan untuk menunjang penelitian ini berupa foto proses pembuatan bahan dasar pewarna benang tenun dan proses penenunan di desa Pringgasela tersebut.

HASIL

Hasil wawancara dari 3 narasumber ditemukan bahwa dari data 420 orang penenun tersebut hanya 168 orang (40\%) yang masih aktif menenun di rumah masing-masing, para penenun terbagi menjadi 5 kelompok yang terdiri dari 20 hingga 30 orang penenun. Untuk menenun satu lembar kain dengan ukuran 3meter x $60 \mathrm{~cm}$ melibatkan kurang lebih $4-7$ orang. Alat tenun yang digunakan oleh para penenun di Desa Pringgasela adalah jenis Gedokan, sebuah alat tenun manual yang dikerjakan hanya oleh perempuan. Dari 168 orang penenun aktif hanya sedikit yang mau menenun dengan menggunakan benang yang dicelup dengan pewarna alam. Sisanya menenun dengan menggunakan benang yang diwarna sintetis, hal ini disebabkan karena tidak semua penenun adalah pencelup benang (dyer).

Tradisi mencelup benang dengan pewarna alam merupakan warisan dari keluarga yang turun-temurun sebagai penenun dan tidak semua penenun mendapat warisan tersebut. Selain itu proses mencelup benang dengan pewarna alam membutuhkan waktu yang sangat lama karena proses yang rumit. Harga jual tenun sesek pewarna alam akan sangat mahal yang mengakibatkan perputaran modal usaha seringkali terhambat karena wisatawan yang berkunjung seringkali kurang memahami tentang kerumitan proses dari tenun pewarna alam (Juniati, 2019).

Proses pembuatan Tenun Sesek Pringgasela ini, antara lain sebagai berikut.

\section{Teknik Pewarnaan Benang Tenun}

Terdapat 3 macam benang yang dipakai dalam menenun tenun sesek ini, yaitu: benang katun, benang kapas dan benang merser. Ketiga macam benang tersebut berbahan dasar sama yaitu kapas namun dengan finishing yang berbeda. Benang katun memiliki kualitas yang lebih baik dari benang kapas dilihat dari pilinan benangnya sehingga menjadi lebih kuat. Benang merser adalah yang terbaik karena selain pilinan yang lebih rapat serta proses merser (mercerized) yang membuat benang jenis ini menjadi lebih kuat, halus dan berkilau. Pewarna benang yang digunakan menggunakan bahan-bahan dari tumbuhan, dan menghasilkan berbagai macam warna yang dibutuhkan untuk membuat motif sesuai keinginan penenun. Seperti yang telah diteliti sebelumnya oleh Darma dan Priyadi (2015) bahwa bahan-bahan pewarna yang banyak dipakai di daerah Nusa Tenggara Barat antara lain: Mangifera Indica (Mangga), Indigofera Tinctori (Tarum) Swietenia Mahagoni (Mahoni). Namun beberapa bahan lain yang menjadi temuan baru dalam penelitian yang dilakukan Juniati (2019) yaitu adanya bahan baru dalam pencelupan benang Tenun Sesek yaitu penggunaan kulit manggis (Garcinia mangostana L), kulit degan muda (Cocos nucifera) dan kulit batang kayu nangka (Artocarpus heterophyllus) dan banyak juga menggunakan kulit secang (Caesalpinia sappan L) namun kulit secang ini dibeli dari pulau Jawa. Warna-warna yang dihasilkan dari bahan-bahan ini tergantung dengan penggunaan fiksasi tawas ( $\mathrm{Kal}(\mathrm{SO} 4) 2)$, kapur $\left(\mathrm{Ca}(\mathrm{OH})_{2}\right)$ atau tunjung ( $\mathrm{Fe}$ SO4). Bahan-bahan pewarna seperti kulit kayu nangka atau mahoni, kulit buah degan ataupun manggis tersebut dapat dipakai secara berulang-ulang dengan cara direbus. Jika bahan-bahan 
ini sudah tidak dapat memberi warna lagi, dibakar untuk kebutuhan memasak, abunya bisa dipakai untuk membersihkan lumut dan mencuci peralatan dapur. Pasta dari endapan daun tarum menghasilkan warna biru indigo. Untuk menghasilkan warna hitam, membutuhkan proses pewarnaan yang lama karena benang harus di celup di larutan indigo dan diperam didalam tanah secara beruulang-ulang hingga mendapatkan warna yang diinginkan. Ranting dan daun tarum setelah proses perendaman dapat ditiriskan dan kemudian dibakar. Abu dari ranting dan daun tarum dijadikan pupuk alami di sawah dan menjadi campuran pewarna saat mencelup benang. Hasil pewarnaan antara bahan dan fiksasi tersebut dapat dilihat pada tabel di bawah ini.

\section{Tabel 2}

Keragaman Bahan-Bahan Alam Sebagai Pewarna Alam Tenun Sesek Desa Pringgasela

\begin{tabular}{|c|c|c|c|}
\hline Bahan & $\begin{array}{l}\text { Bagian yang } \\
\text { digunakan }\end{array}$ & Fiksasi & $\begin{array}{c}\text { Warna yang } \\
\text { dihasilkan }\end{array}$ \\
\hline Mangifera Indica (Mangga) & Daun & Tawas (Kal (SO4)2) & Kuning \\
\hline Mangifera Indica (Mangga) & Daun & Tunjung (Fe SO4) & Hijau lumut \\
\hline Indigofera Tinctori (Tarum) & Daun, batang & --- & Biru \\
\hline Indigofera Tinctori (Tarum) & Daun, batang & $\begin{array}{l}\text { Tanah yang tidak } \\
\text { pernah terkena } \\
\text { pupuk kimia }\end{array}$ & Hitam \\
\hline Swietenia Mahagoni (Mahoni) & Kulit batang & Tawas (Kal (SO4)2) & $\begin{array}{c}\text { Coklat } \\
\text { kemerahan }\end{array}$ \\
\hline Swietenia Mahagoni (Mahoni) & Kulit batang & Tunjung (Fe SO4) & Coklat tua \\
\hline $\begin{array}{l}\text { Garcinia mangostana } L \text { (manggis) }+ \\
\text { Cocos nucifera (degan) }+\end{array}$ & Kulit buah & Tawas (Kal (SO4)2) & Teracotta \\
\hline \multicolumn{4}{|l|}{ Caesalpinia sappan L (sepang) } \\
\hline $\begin{array}{l}\text { Garcinia mangostana } L \text { (manggis) + } \\
\text { Cocos nucifera (degan) }+\end{array}$ & Kulit buah & Tunjung (Fe SO4) & Ungu \\
\hline \multicolumn{4}{|l|}{ Caesalpinia sappan L (sepang) } \\
\hline
\end{tabular}

\section{Persiapan Menenun}

Hal-hal yang harus dilakukan sebelum penenunan Tenun Sesek, antara lain: 1) Nenasin benang, merupakan proses membasahi benang dengan tajin ketan atau bubur ketan. Pemberian bubur ketan ini berfungsi memperkuat permukaan benang, pilinan benang karena dalam proses menenun, benang akan selalu bergesekan satu sama lain. Sisa bubur ketan yang masih tersisa dapat disimpan berhari-hari dan masih dapat digunakan lagi sehingga tidak perlu dibuang jika ada sisa; 2) Memuyun, memintal benang; 3) Menghane, Membentuk motif garis untuk benang lungsin; 4) Nyusuk Suri, memasukkan benang ke dalam suri (sisir tenun); 5) Begulung, menggulung benang lungsin sesuai dengan panjang kain sesekan. Kain tenun yang dihasilkan dengan menggunakan alat gedokan ini kurang lebih 3 meter, dan untuk mempermudah penenun bekerja, benang lungsin yang sudah diatur motifnya digulung dan dibentangkan hanya sepanjang kaki penenun saja; 6) Meleting, menggulung benang pakan. Benang pakan adalah benang yang akan bersilangan di dalam bentangan benang lungsin dan untuk mempermudah proses menenun, benang digulung dan dimasukkan kedalam tabung yang terbuat dari bambu (Juniati ,2019). 


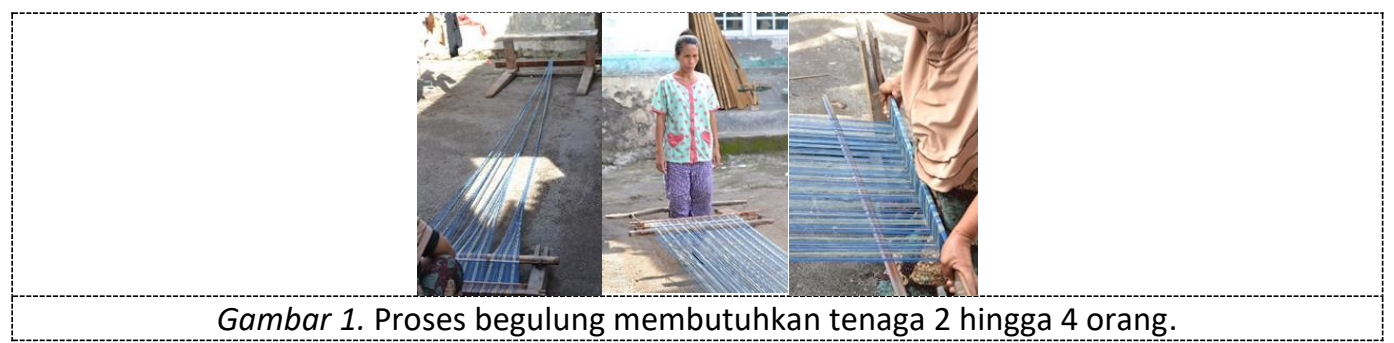

\section{Menenun}

Proses selanjutnya adalah sesek atau menenun. Kain yang ditenun disebut sesek karena selama proses terdengar suara "sek sek". Proses menenun adalah proses yang paling lama di antara proses yang lain. Seorang penenun memiliki target menenun sepanjang satu hasta setiap harinya, sehingga satu lembar kain selesai ditenun antara 10 hingga 14 hari dengan kegiatan kesehariannya.

\section{Hasil Tenun}

Hasil tenun yang menggunakan pewarna alam dan sintetis tentu berbeda. Tenun yang menggunakan pewarna sintetis sangat cerah, solid dan beraneka warna. Tenun yang menggunakan pewarna alam berwarna lebih pucat dengan pilihan warna yang tidak banyak, hal ini menjadi salah satu alasan banyak penenun di desa ini menggunakan benang tenun yang diwarnai dengan pewarna kimia untuk mengikuti permintaan pasar yang menginginkan warnawarna cerah dan terang. Selain itu, dengan proses yang lebih lama harga jual tenun yang menggunakan pewarna alam lebih mahal. Berikut ini adalah berbagai motif dari Tenun sesek yang menggunakan pewarna alam.

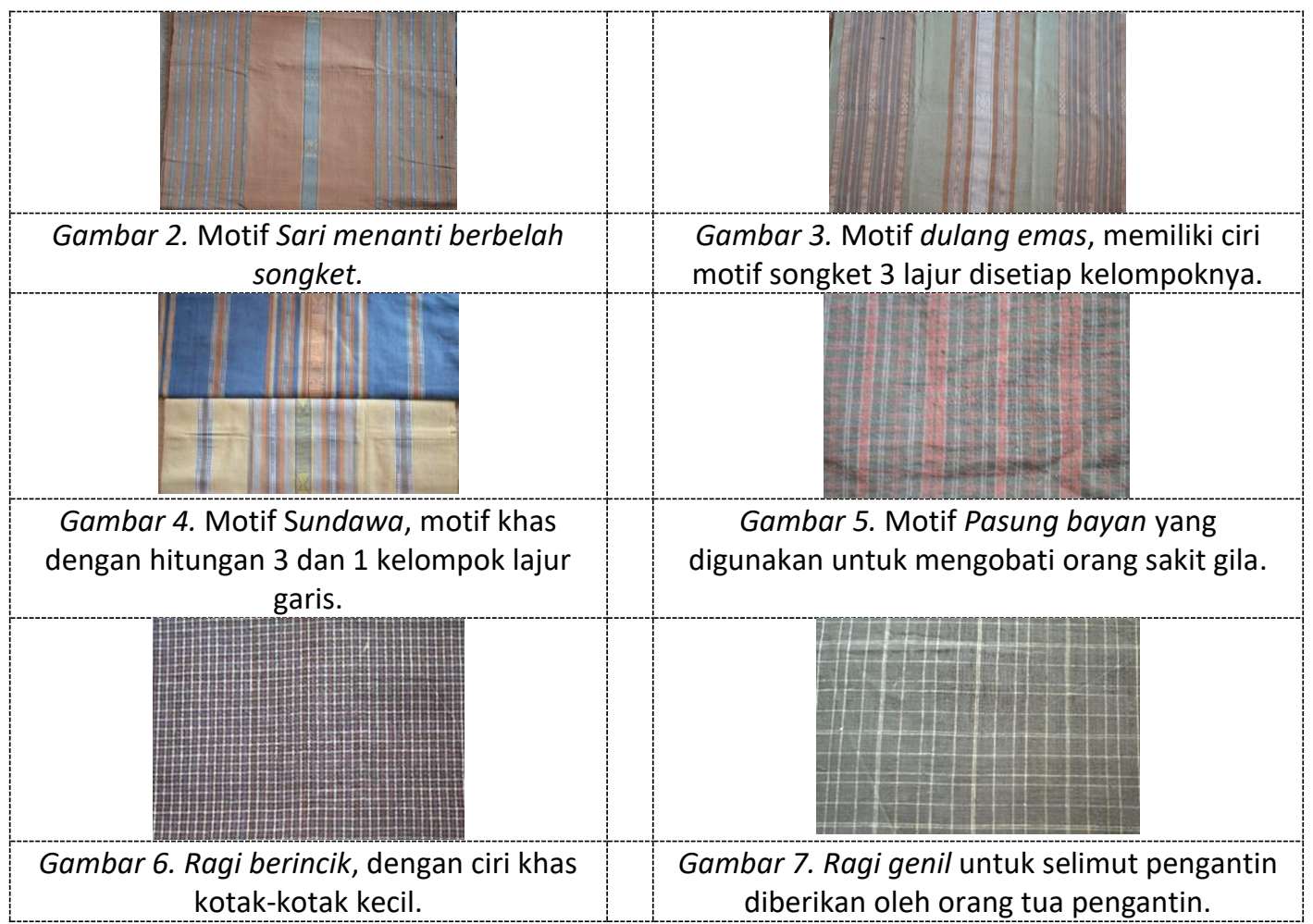

Motif Pasung bayan, Ragi berincik dan Ragi genil merupakan motif leluhur yang berusia di atas 70 tahun dan disimpan secara turun-temurun. Motif-motif leluhur yang banyak disimpan oleh para penenun memiliki kecenderungan bermotif kotak dan berwarna gelap seperti biru tua atau hitam dengan menggunakan teknik pewarnaan yang lebih lama dan lebih 
rumit, antara lain untuk mendapatkan warna hitam celupan benang harus diperam dalam gentong dan dikubur di tanah selama berbulan-bulan. Motif Sundawa, Sari Menanti berbelah songket dan Dulang Emas merupakan motif pengembangan menyesuaikan keinginan pasar. Motif-motif pengembangan ini memiliki ciri khas garis berkelompok, sesekali diberi motif songket dengan benang pakan jika menggunakan pewarna alam maka warna-warna pilihan adalah aneka warna pastel menyesuaikan bahan pewarna yang tersedia saat itu.

\section{BAHASAN}

Proses pembuatan Tenun Sesek Pringgasela telah mengalami perubahan proses, salah satunya adalah tidak melakukan pemintalan benang dari serat kapas. Hal ini dikarenakan sudah tidak ada petani yang menanam tanaman kapas karena adanya perubahan nilai dimasyarakat karena kebutuhan pangan di desa tersebut lebih tinggi dan menanam bahan pokok seperti padi serta palawija memiliki nilai ekonomi yang lebih tinggi daripada tanaman kapas. Selain perubahan nilai karena kebutuhan pangan, juga dikarenakan permintaan masyarakat yang tinggi akan Tenun Sesek Pringgasela yang berharga lebih terjangkau sehingga akan lebih menguntungkan jika menggunakan benang jadi yang siap tenun (Juniati, 2019).

Warna-warna pastel yang mendominasi pada Tenun Sesek Pringgasela dengan pewarnaan alam, juga disebabkan oleh mulai berkurangnya penenun yang memiliki kemampuan mencelup benang tenun dengan pewarnaan alam. Warna tenun yang gelap seperti hitam, biru tua, hijau tua dan merah tua yang dicelup dengan pewarna alam membutuhkan proses yang lebih lama dan rumit, hal ini tentu saja membuat kerugian bagi penenun karena ongkos produksi yang lebih mahal namun masyarakat menginginkan harga jual yang lebih terjangkau. Akibatnya, penggunaan benang jadi siap tenun yang diwarna secara kimia merupakan solusi yang menguntungkan bagi penenun di desa Pringgasela saat ini.

Berikut ini adalah hasil akhir dari setiap proses pembuatan Tenun Sesek.

\section{Proses Persiapan}

Persiapan menenun terdiri atas nenasin benang, Memuyun, Menghane, Nyusuk Suri, begulung dan Meleting. Limbah yang dihasilkan dari proses ini adalah kanji yang masih bisa digunakan untuk nenasin benang berikutnya. Sisa-sisa benang putus yang masih bisa digunakan untuk proses berikutnya yaitu digabung dan dipilin pada saat proses memuyun.

\section{Proses pewarnaan benang}

Bahan pewarnaannya diambil dari lingkungan sekitar menyesuaikan musim yang ada seperti musim manggis maka kulit manggis dimanfaatkan sebagai zat pewarna. Jika ada pohon nangka atau mengkudu yang tumbang maka potongan-potongan kecilnya dimanfaatkan sebagai zat warna. Limbah yang dihasilkan dari proses ini antara lain sisa-sisa pewarna benang, masih bisa digunakan hingga 3-5 kali pencelupan. Jika sudah tidak menghasilkan warna, dapat menjadi bahan bakar perebusan zat warna, abu bakarnya dapat digunakan sebagai pembersih lumut serta alat-alat dapur. Tangkai dan daun bekas rendaman indigo dikeringkan terbih dahulu kemudian dibakar dapat menjadi pupuk tanaman palawija dan campuran pasta indigo.

\section{Proses menenun dan finishing}

Limbah yang dihasilkan dari proses ini hampir tidak ada, jika ada berupa sedikit sisa benang yang putus dan bisa dibakar dan abunya untuk campuran pewarna benang.

\section{SIMPULAN}

Berdasarkan hasil dan pembahasan di atas dapat disimpulkan bahwa Tenun Sesek yang ditemui di Desa Pringgasela terdapat dua jenis yaitu: 1 ) Tenun Sesek dengan pewarnaan alam yang memiliki ciri khas warna kusam dan pastel dengan varian warna yang terbatas; dan 2) Tenun Sesek dengan pewarnaan kimia yang memiliki ciri khas warna yang solid dan intens seperti hitam dan warna-warna gelap lainnya, warna cerah serta dengan pilihan warna yang 
lebih bervariasi. Dari segi motif yang banyak dijumpai di Pringgasela adalah motif-motif pengembangan dengan variasi warna yang beragam baik pewarna alam maupun kimia. Variasi motif dan warna yang berkembang disebabkan oleh berubahnya nilai sosial dan ekonomi di Desa Pringgasela. Proses pembuatan Tenun Sesek Pringgasela ini terdapat pemanfaatan limbah yang dihasilkan pada setiap prosesnya, dimulai dari proses persiapan hingga penyelesaian tenunan. Proses pemanfaatan limbah ini dimaksudkan untuk menjaga lingkungan sekitar agar sedapat mungkin bebas limbah serta tidak mengeksploitasi alam. Proses pembuatan Tenun Sesek yang menggunakan pewarna alam ini dapat menjadi referensi bagi penenun, perajin atau artisan wastra lainnya dalam penciptaan karya mereka. Sayangnya para generasi muda di Desa Pringgasela ini masih enggan untuk meneruskan teknik pembuatan Tenun Sesek yang menggunakan pewarna alam sementara nilai-nilai seperti berkarya tanpa mengeksploitasi alam, tidak merusak alam dengan limbah saat ini telah menjadi isu sosial yang mulai diperhatikan, mengingat masyarakat saat ini pun mulai melirik produk-produk fashion yang ramah lingkungan.

Berdasarkan simpulan tersebut dapat dijadikan rekomendasi bagi peneliti lain untuk mengembangkan penelitian tentang Tenun Sesek Pringgasela ini terkait desain produk maupun fashion, retail serta peningkatan minat generasi muda sebagai regenerasi penenun, dan minat konsumen terhadap Tenun Sesek Pringgasela ini.

\section{PUSTAKA ACUAN}

Juniati, N, 2019, Slow - Fashion: Case Study of Tenun Sesek as local wisdom from Pringgasela, East Lombok, West Nusa Tenggara E-Proceeding International Conference on Informatics, Technology, and Engineering (Incite), Volume 2, ISSN: 2686-5955.

Kartika, S, 2007, Ragam Kain Tradisional Indonesia Tenun Ikat, Jakarta: PT. Gramedia Pustaka Utama.

\section{BIBLIOGRAFI}

Darma, IDP, \& Priyadi, A, 2015, Keragaman tumbuhan sebagai pewarna pada kerajinan tenun suku Sasak: Studi kasus di Desa Sukarara, Kecamatan Jonggat, Kabupaten Lombok Tengah, Nusa Tenggara Barat, Pros Sem Nas Masy Biodiv Indon, 1(4), Juli 2015. ISSN: 2407-8050.

Huda, M, 2018, Perlindungan hukum terhadap kerajinan tenun songket di Desa Pringgasela menurut Hukum Hak Kekayaan Intelektual Indonesia, FH Universitas Negeri Mataram.

Fletcher, K, 2008, Sustainable fashion and textiles, London: Earthscan.

Gillow, J, \& Sentence, B, 1999, World textile, London: Thames and Hudson Ltd.

Institut, Goethe, 2017, Ikat eCut, textilien zwischen kunst, design, tradition und technologie, Indonesia: Goethe-Institut Indonesien.

Mardiyanti \& Ismadi, 2016, Kain tenun Tradisional Dusun Sade, Rembitan, Pujut, Lombok Tengah, Nusa Tenggara Barat, FBS Universitas Negeri Yogyakarta.

Maxwell, R, 2003, Textiles of Southeast Asia, Hongkong: Periplus Ltd.

\section{Acknowledgments}

Ucapan terima kasih kepada Innak wiwin dan Ibu Idayanti sebagai Penenun senior serta Ibu Ria selaku pendamping LPSDM (Lembaga Pengembangan Swadaya Mitra) di Dusun Gubuk daya Desa Pringgasela sebagai Narasumber dalam penelitian ini. 